\title{
O FATOR DE IMPACTO dAS PUBLICAÇÕES CIENTíficAS
}

Maria Helena Palucci Marziale ${ }^{1}$

Isabel Amélia Costa Mendes ${ }^{2}$

\begin{abstract}
Atualmente muito se tem discutido sobre a qualidade dos periódicos científicos da Enfermagem brasileira e sobre os instrumentos utilizados para sua avaliação ${ }^{(1)}$. Embora existam diferentes formas para avaliar um periódico científico, o fator de impacto das publicações vem apresentando notoriedade e priorização pelas agências de fomento.
\end{abstract} Vislumbrando informar nossos leitores sobre essa forma avaliativa direcionamos esse editorial a esta questão.

O fator de impacto começou a ser considerado como uma maneira de avaliar as revistas científicas a partir da década 60 do século XX, quando Eugene Garfield, diretor do Institute of Scientific Information (ISI) e criador da base de dados bibliográfica Science Citation Index $(\mathrm{SCl})$, elegeu esse instrumento, que determina a freqüência com que um artigo é citado, como forma de classificar e avaliar as revistas incluídas na referida base de dados ${ }^{(2-3)}$.

O valor do fator de impacto é obtido dividindo-se o número total de citações dos artigos, acumulados nos últimos dois anos, pelo total acumulado de artigos publicados pela revista no referido período.

Somente os periódicos indexados no ISI são considerados para o cálculo do fator de impacto internacional. Para que um periódico seja contemplado a ingressar nesta base de dados ele deve reunir requisitos como pontualidade de publicação e cumprimento das normas internacionais de editoração (título informativo, correção das referências citadas, informações completas dos autores, pelo menos conter título, resumo e descritores em inglês e processo de revisão dos artigos a serem publicados por pares - peer review). O critério de seleção adotado é rigoroso uma vez que o ISI tem o compromisso de oferecer cobertura completa dos periódicos mais importantes e influentes do mundo para atualização de informações e entende que a cobertura completa deve ser feita não pela quantidade e sim pela qualidade $^{(4)}$. A referida base de dados é seletiva e considera que a maior parte dos trabalhos científicos mais importantes é publicada em relativamente poucos periódicos.

O ISI possui mais de 8600 revistas internacionais nas áreas de ciências biológicas e exatas, sociais e humanas. Essas áreas estão incluídas em três bases de dados:

- Arts and Humanities Citation Index (A\&HCl) informações de artigos procedentes de cerca de 1120 revistas relacionadas com arte e humanidades. Inclui também artigos relevantes procedentes de outras 7000 revistas de ciência e tecnologia; - Science Citation Index (SCl) abarca todas as áreas científicas, tanto básicas como aplicadas. Inclui aproximadamente 3500 publicações;

- Social Sciences Citation Index (SSCI) contempla todas as disciplinas do campo das ciências sociais procedentes de 1755 revistas. Também inclui artigos procedentes de outras 3300 revistas. Esta base de dados é composta por 56 áreas temáticas, sendo algumas delas: Sociologia, Antropologia, Geografia, História, Ciências da Comunicação, Ciências Políticas, Psicologia e Enfermagem ${ }^{(4)}$.

Anualmente elabora o Journal Citation Report (JCR), Social Sciences Editions e Sciences Editions contendo os indicadores bibliométricos de repercussão das revistas (fator de impacto, índice de imediacidade, que determina a rapidez com que um artigo é lido e citado, vida média das citações e a classificação no ranking mundial).

Em estudo recentemente realizado sobre as revistas de Enfermagem contempladas no ISI e no JCR foi

Editores da Revista Latino-Americana de Enfermagem da Escola de Enfermagem de Ribeirão Preto, da Universidade de São Paulo, Centro Colaborador da OMS para o desenvolvimento da pesquisa em enfermagem: ${ }^{1}$ Professor Livre-Docente, e-mail: marziale@eerp.usp.br; ${ }^{2}$ Professor Titular, e-mail: iamendes@eerp.usp.br 
constatada a inclusão de apenas 38 revistas, indexadas principalmente no $\mathrm{SSCl}$, sendo a maioria de origem anglosaxônica, com a liderança da enfermagem norte americana ${ }^{(5)}$.

Dados referenciais e estatísticos de uso de citações, inclusive o fator de impacto começaram a ser calculados e utilizados para avaliação da produção científica publicada na América Latina e Caribe há cerca de quatro anos pela Scientific Eletronic Library Online (SciELO) que agrega em sua coleção um conjunto de periódicos científicos de diferentes áreas do saber.

Para o ingresso na Coleção SciELO o periódico passa por um processo seletivo que contempla os requisitos das normas internacionais de editoração e a indexação do periódico em bases de dados internacionais.

Através da divulgação online acreditamos que o conhecimento científico produzido pela Enfermagem brasileira e latino-americana possa conquistar visibilidade no cenário internacional e a avaliação do fator de impacto através da SciELO parece-nos ser mais viável para a nossa realidade ${ }^{(6)}$.

\section{REFERÊNCIAS BIBLIOGRÁFICAS}

1. Mendes IAC, Marziale MHP. A avaliação por pares em divulgação científica. Rev Latino-am Enfermagem 2001 nov-dez; 9 (6): $1-2$

2. Garfield E. The impact factor. Current Coments (print edition). 1994 June 20; 25:3-8.

3. Garfield E. Fortnightly review: how can impact factors be improved? Br Med J 1996; 313:411-3.

4. International Scientific Information. ISI. Products \& Services [online]. 2002. [cited 2001 Nov 21]. Available from: URL: http:// www.isinet.com.

5. Cortés NIO, Martinez MR, Garcia JC. Factor de impacto en las Revistas de Enfermería. Universidad de Alicante; 2001.

6. Marziale MHP, Mendes IAC. Uma grande conquista: Revista Latino-Americana de Enfermagem ingressa na coleção Scielo.

Rev Latino-am Enfermagem 2002 jan-fev; 10(1):1-2. 


\title{
THE IMPACT FACTOR OF SCIENTIFIC JOURNALS
}

Maria Helena Palucci Marziale ${ }^{1}$

Isabel Amélia Costa Mendes ${ }^{2}$

\begin{abstract}
A lot has been discussed about the quality of Brazilian scientific nursing journals and the instruments used for their evaluation ${ }^{(1)}$. Although many different criteria can be applied in order to evaluate a scientific journal, the impact factor of publications has been given notoriety and priority by funding agencies. Aiming at informing our readers with regard to this form of evaluation, we have focused this editorial on that topic.

The impact factor began to be considered as a form of evaluation of scientific journals in the 1960s, which was when Eugene Garfield, director of the Institute of Scientific Information (ISI) and creator of the bibliographic database Science Citation Index (SCI), elected this instrument, which determines how frequently an article is cited, as a form of classification and evaluation for journals included in that database ${ }^{(2-3)}$.

The value of the impact factor is obtained by dividing the total number of article citations accumulated in the
\end{abstract} past two years by the total number of articles published by the journal in the same period.

Only articles which are indexed in the ISI are taken into account to calculate the international impact factor. In order for a journal to be contemplated with its inclusion in that database, it must meet certain requirements such as punctuality in publication and compliance with international publishing standards (informative title, correction of cited references, complete author information, presentation of at least the title, abstract and key words in English and peer review of articles to be published. The selection criterion adopted is rigorous as the ISI is committed to offering total coverage of the major and most influential journals in the world in order to update information and understands that a complete coverage should be conducted not on basis of quantity, but on quality ${ }^{(4)}$. The above-mentioned database is selective and considers that the majority of the most relevant scientific works are published in relatively few journals.

The ISI has over 8,600 international journals in the areas of Sciences, Arts and humanities. These areas are included in three databases:

- Arts and Humanities Citation Index (A\&HCl) provides information on articles from approximately 1,120 journals concerning Arts and Humanities. It also includes relevant articles from other 7,000 journals related to Science and Technology;

- Science Citation Index (SCl) includes all the scientific areas, both basic and applied, with approximately 3,500 publications;

- Social Sciences Citation Index (SSCI) includes all the disciplines in the field of social sciences from 1,755 journals. It also includes articles from other 3,300 journals. This database comprises 56 thematic areas, some of which are: Sociology, Anthropology, Geography, History, Communication Sciences, Political Sciences, Psychology and Nursing ${ }^{(4)}$.

On an annual basis, it compiles the Journal Citation Report (JCR), Social Sciences Editions and Sciences Editions containing bibliometric indicators of its journals' repercussion (impact factor, immediacy index, which determines how soon an article is read and cited, average life span of citations and classification in the world ranking).

In a recently conducted study on nursing journals contemplated by the ISI and the JCR, the inclusion of only 38 journals was observed. They were mainly indexed in the SSCI and of Angle-Saxon origin with the leadership of North American nursing ${ }^{(5)}$.

Editors of Latin American Journal of Nursing of Ribeirão Preto of the University of São Paulo at Ribeirão Preto College of Nursing - WHO Collaborating Centre for Nursing Research Development: ${ }^{1}$ Associate Professor, e-mail: marziale@eerp.usp.br; ${ }^{2}$ Full Professor, e-mail: iamendes@eerp.usp.br 
Referential and statistical data concerning citation use, including the impact factor, began to be calculated and used for the evaluation of the scientific production published in Latin America and the Caribbean approximately four years ago by the Scientific Electronic Library Online (SciELO), which aggregates, in its collection, a set of scientific journals from different areas of knowledge.

In order to be included in the SciELO Collection, the journal undergoes a selection process that contemplates the requirements established by international publication standards and the journal's indexation in international databases.

We believe that the on-line dissemination of the scientific knowledge produced by Brazilian and Latin American Nursing can achieve visibility in the international scenario and the evaluation of its impact factor through SciELO seems to be the most feasible for our reality ${ }^{(6)}$.

\section{REFERENCES}

1. Mendes IAC, Marziale MHP. A avaliação por pares em divulgação científica. Rev Latino-am Enfermagem 2001 nov-dez; 9 (6): 1-2.

2. Garfield E. The impact factor. Current Coments (print edition). 1994 June 20; 25:3-8.

3. Garfield E. Fortnightly review: how can impact factors be improved? Br Med J 1996; 313:411-3.

4. International Scientific Information. ISI. Products \& Services [online]. 2002. [cited 2001 Nov 21]. Available from: URL: http:// www.isinet.com.

5. Cortés NIO, Martinez MR, Garcia JC. Factor de impacto en las Revistas de Enfermería. Universidad de Alicante; 2001.

6. Marziale MHP, Mendes IAC. Uma grande conquista: Revista Latino-Americana de Enfermagem ingressa na coleção Scielo. Rev Latino-am Enfermagem 2002 jan-fev; 10(1):1-2. 


\title{
EL FACTOR DE IMPACTO dE LAS PUBLICACIONES CIENTÍfICAS
}

Maria Helena Palucci Marziale ${ }^{1}$

Isabel Amélia Costa Mendes ${ }^{2}$

\begin{abstract}
Actualmente se ha discutido mucho sobre la calidad de las revistas científicas de la Enfermería brasileña y sobre los instrumentos utilizados para su evaluación ${ }^{(1)}$. A pesar de que existan diferentes formas para evaluar una revista científica, el factor de impacto de las publicaciones viene presentando notoriedad y esta siendo prioritario para las agencias de fomento. Buscando informar a nuestros lectores sobre esa forma de evaluación, es que estamos enfocando las ideas generales de este editorial.

El factor de impacto comenzó a ser considerado como una manera de evaluar las revistas científicas a partir de la década de los años 60 en el siglo XX, cuando Eugene Garfield, director del Institute of Scientific Information (ISI) y creador de la base de datos bibliográfica Science Citation Index ( $\mathrm{SCl}$ ), eligió ese instrumento, que determina la frecuencia con que un articulo es citado, como forma de clasificar y avaluar las revistas incluidas en la referida base de datos $^{(2-3)}$
\end{abstract}

El valor del factor de impacto es obtenido dividiendo el numero total de citaciones de los artículos acumulados en los últimos dos años por el total acumulado de artículos publicados por la revista en el periodo referido.

Solamente las revistas indexadas en el ISI son consideradas para el calculo del factor de impacto internacional. Para una revista sea contemplada para ingresar en esta base de datos, debe reunir requisitos como puntualidad en la publicación y cumplimiento de las normas internacionales de editoriación (título informativo, corrección de las referencias citadas, informaciones completas de los autores, por lo menos contener título, resumen y descriptores en inglés y proceso de revisión de los artículos a ser publicados por pares -peer review-). El criterio de selección adoptado es riguroso una vez que el ISI tiene el compromiso de ofrecer cobertura completa de las revistas más importantes e influyentes del mundo para actualización de informaciones y entiende que la cobertura completa debe ser hecha no por la cantidad si no por la calidad ${ }^{(4)}$. La referida base de datos es selectiva y considera que la mayor parte de los trabajos científicos más importantes es publicada en relativamente pocas revistas. El ISI posee más de 8600 revistas internacionales en las áreas de ciencias biológicas y exactas sociales y humanas. EN esas áreas están incluidas en tres bases de datos:

- Arts and Humanities Citation Index (A\&HCl) informaciones de artículos procedentes de cerca de 1120 revistas relacionadas con arte y humanidades.

- Science Citation Index (SCI) Incluye también artículos relevantes procedentes de otras 7000 revistas de ciencia y tecnología; Abarca todas las áreas científicas, tanto básicas como aplicadas. Incluye aproximadamente 3500 publicaciones; Contempla todas las disciplinas del campo de las ciencias sociales procedentes de 1755 revistas. También incluye artículos procedentes de otras 3300 revistas.

- Social Sciences Citation Index (SSCl) Esta base de datos está compuesta por 56 áreas temáticas, siendo algunas de ellas: Sociología, Antropología, Geografía, Historia, Ciencias de la Comunicación, Ciencias Políticas, Psicología y Enfermería ${ }^{(4)}$.

Anualmente elabora el Journal Citation Report (JCR), Social Sciences Editions e Sciences Editions conteniendo los indicadores bibliometricos de repercusión de las revistas (factor de impacto, índice de inmediaticidad, que determina

Editores de la Revista Latinoamericana de Enfermería de la Escuela de Enfermería de Ribeirão Preto de la Universidad de São Paulo, Centro Colaborador de la OMS para el desarrollo de la investigación en enfermería: ${ }^{1}$ Professor Libre-Docente, correo electrónico: marziale@eerp.usp.br;

${ }^{2}$ Professor Titular, correo electrónico: iamendes@eerp.usp.br 
la rapidez con que un artículo es leído y citado, vida promedio de las citaciones y clasificación en el ranking mundial).

En un estudio realizado recientemente sobre las revistas de enfermería contempladas en el ISI y en el JCR se constató la inclusión de apenas 38 revistas, indexadas principalmente en el $\mathrm{SSCl}$, siendo la mayoría de origen anglosajona, con liderazgo de la enfermería norteamericana ${ }^{(5)}$. Datos referenciales y estadísticos de uso de citaciones, inclusive el factor de impacto comenzaron a ser calculados y utilizados par ala evaluación de la producción científica publicada en América Latina y el Caribe hace cerca de cuatro años por parte de la Scientific Eletronic Library Online (SciELO) que agrega en su colección un conjunto de revistas científicas de diferentes áreas del saber. Para el ingreso en la colección SciELO la revista pasa por un proceso selectivo que contempla los requisitos de las normas internacionales de editoriación e indexación de la revista en las bases de datos internacionales.

A través de la divulgación on-line creemos que el conocimiento científico producido por la enfermería brasileña y latinoamericana pueda conquistar visibilidad en el escenario internacional y la evaluación del factor de impacto a través de la SciELO nos parece ser más viable para nuestra realidad ${ }^{(6)}$.

\section{REFERENCIAS BIBLIOGRÁFICAS}

1. Mendes IAC, Marziale MHP. A avaliação por pares em divulgação científica. Rev Latino-am Enfermagem 2001 nov-dez; 9 (6): 1-2.

2. Garfield E. The impact factor. Current Coments (print edition). 1994 June 20; 25:3-8.

3. Garfield E. Fortnightly review: how can impact factors be improved? Br Med J 1996; 313:411-3.

4. International Scientific Information. ISI. Products \& Services [online]. 2002. [cited 2001 Nov 21]. Available from: URL: http:// www.isinet.com.

5. Cortés NIO, Martinez MR, Garcia JC. Factor de impacto en las Revistas de Enfermería. Universidad de Alicante; 2001.

6. Marziale MHP, Mendes IAC. Uma grande conquista: Revista Latino-Americana de Enfermagem ingressa na coleção Scielo. Rev Latino-am Enfermagem 2002 jan-fev; 10(1):1-2. 